\title{
38. MAGNETIC REVERSAL STRATIGRAPHY OF JURASSIC OCEANIC CRUST FROM HOLE 801C DOWNHOLE MAGNETOMETER MEASUREMENTS ${ }^{1}$
}

\author{
Hisao Ito, ${ }^{2}$ Yoshifumi Nogi, ${ }^{3}$ and Roger L. Larson ${ }^{4}$
}

\begin{abstract}
A downhole magnetometer log obtained from Hole $801 \mathrm{C}$ during Ocean Drilling Program Leg 144 was analyzed to constrain the magnetic character of the Jurassic basement at that location. Hole $801 \mathrm{C}$, drilled during Leg 129, penetrates the uppermost 131 $\mathrm{m}$ of Jurassic oceanic crust beneath $463 \mathrm{~m}$ of sediments in the Pigafetta Basin of the western Pacific Ocean. Magnetic boundaries, apparent inclination, and polarity of magnetization were determined from variations of the horizontal and vertical magnetic fields in the hole.

The magnetized basalts were divided into three principal units based on their magnetization. The first unit, located above 550 meters below seafloor, is characterized by almost no magnetization. The second unit, between 550 and 583 mbsf, mainly has a magnetization that was acquired in the Southern Hemisphere during a reversed polarity chron. In the third unit, below 583 mbsf, magnetization was acquired in the Southern Hemisphere during a normal polarity chron. The intensity of magnetization below $583 \mathrm{mbsf}$ seems to decrease rapidly. A clear change from reversed to normal magnetic polarity was observed between the second and third units.

The basalts with a remanent magnetization acquired in the Southern Hemisphere have retained their primary magnetization, and indicate that at least these basalts were formed at a spreading ridge crest in the Southern Hemisphere in the Middle Jurassic. The cause of weak magnetization of the first unit and the sharp decrease in intensity within the third unit is considered to be a result of strong hydrothermal alteration. Several thin magnetic subunits are observed within the second unit. The magnetization of those subunits was acquired in the Northern Hemisphere during a normal polarity chron. These Northern Hemisphere, normal magnetized segments possibly were caused by secondary magnetization induced by hydrothermal effects. This same section has been interpreted previously to have five separate polarity intervals, all acquired during the Jurassic based on paleomagnetic measurements of the discrete core samples. Our results suggest only two Jurassic polarity intervals of primary magnetization, and that the other polarity units were acquired subsequently, possibly a result of hydrothermal alteration.
\end{abstract}

\section{INTRODUCTION}

\section{Hole 801C}

Hole $801 \mathrm{C}$ was drilled during Ocean Drilling Program (ODP) Leg 129 and penetrated the uppermost $131 \mathrm{~m}$ of Jurassic oceanic crust beneath $463 \mathrm{~m}$ of sediments in the Pigafetta Basin of the western Pacific Ocean (Lancelot, Larson, et al., 1990). Hole 801C penetrated three distinct petrologic intervals (Fig. 1). The uppermost interval is composed of alkali basalts and has been interpreted as having oceanisland affinity (Floyd and Castillo, 1992). Below the alkali basalts is a hydrothermal deposit primarily composed of quartz-cemented, yellow goethite. Below the hydrothermal zone lie tholeiitic basalts. The age of the tholeiites is about $167 \mathrm{Ma}$, whereas the alkali basalts are about 10 m.y. younger. The differences in ages and petrology suggest that the alkali basalts were erupted in an off-axis environment (Pringle, 1992).

During Leg 144, logging (one pass of the geophysical string, three passes of the FMS/magnetometer string, and one pass of the geochemical string) and permeability measurements were conducted within the basement section (Shipboard Scientific Party, 1993; Larson et al., 1993; Jarrard et al., this volume; Moos et al., this volume).

Wallick and Steiner (1992) studied the paleomagnetic properties of the recovered core samples obtained during Leg 129 (Fig. 1) and found the following magnetic characteristics of the Hole $801 \mathrm{C}$.

\footnotetext{
${ }^{1}$ Haggerty, J.A., Premoli Silva, I., Rack, F., and McNutt, M.K. (Eds.), 1995, Proc. ODP, Sci. Results, 144: College Station, TX (Ocean Drilling Program).

${ }^{2}$ Geological Survey of Japan, Tsukuba, Ibaraki 305, Japan.

${ }^{3}$ Meteorological Research Institute, Tsukuba, Ibaraki 305, Japan. (Present address: National Institute of Polar Research, 1-9-10 Kaga, Itabashi, Tokyo 173, Japan.)

${ }^{4}$ Graduate School of Oceanography, University of Rhode Island, Narragansett, RI 02882, U.S.A.
}

1. The tholeiitic basalts have natural remanent magnetization (NRM) intensities that are neither significantly weaker nor stronger than those found in most oceanic crustal basalts.

2. The alkali olivine basalts show very low magnetic intensity.

3 . The polarity determined by remanent inclination largely corresponds to igneous flow unit boundaries.

They suggested, based on their measurements of core-sample magnetic properties, that Earth's magnetic field experienced frequent changes in polarity during the Jurassic, and that this period of frequent polarity reversals best explains the very small magnetic anomalies within the Jurassic Quiet Zone. However, the question still remains of the number of primary reversals in this Jurassic Magnetic Quiet Zone section, because the Koenigsberger (Q) ratio determined by Wallick and Steiner (1992) is extremely variable, and there is the possibility that some of the magnetic properties have been seriously altered or degraded after their primary acquisition.

\section{Downhole Magnetometer Logging}

Downhole measurements of the magnetic field in ODP and Deep Sea Drilling Project boreholes are useful counterparts of a paleomagnetic study of core samples to obtain insights about the nature of the magnetic structure of the oceanic crust and magnetic polarity stratigraphy. Because core samples may acquire a secondary magnetization effect during the drilling process (Kikawa and Pariso, 1991; Pariso et al., 1991; Nogi et al., 1995a), the measured NRM for recovered core samples may not accurately represent the in situ magnetization (Pariso and Johnson, 1993). Downhole logging can collect a continuous record of the downhole magnetic field within the borehole, which can be related to the magnetization of the surrounding material, to supplement incomplete recovery of paleomagnetic samples from the holes, and also to give us independent information of the magnetization. Therefore, combining the results of core sample measurements 


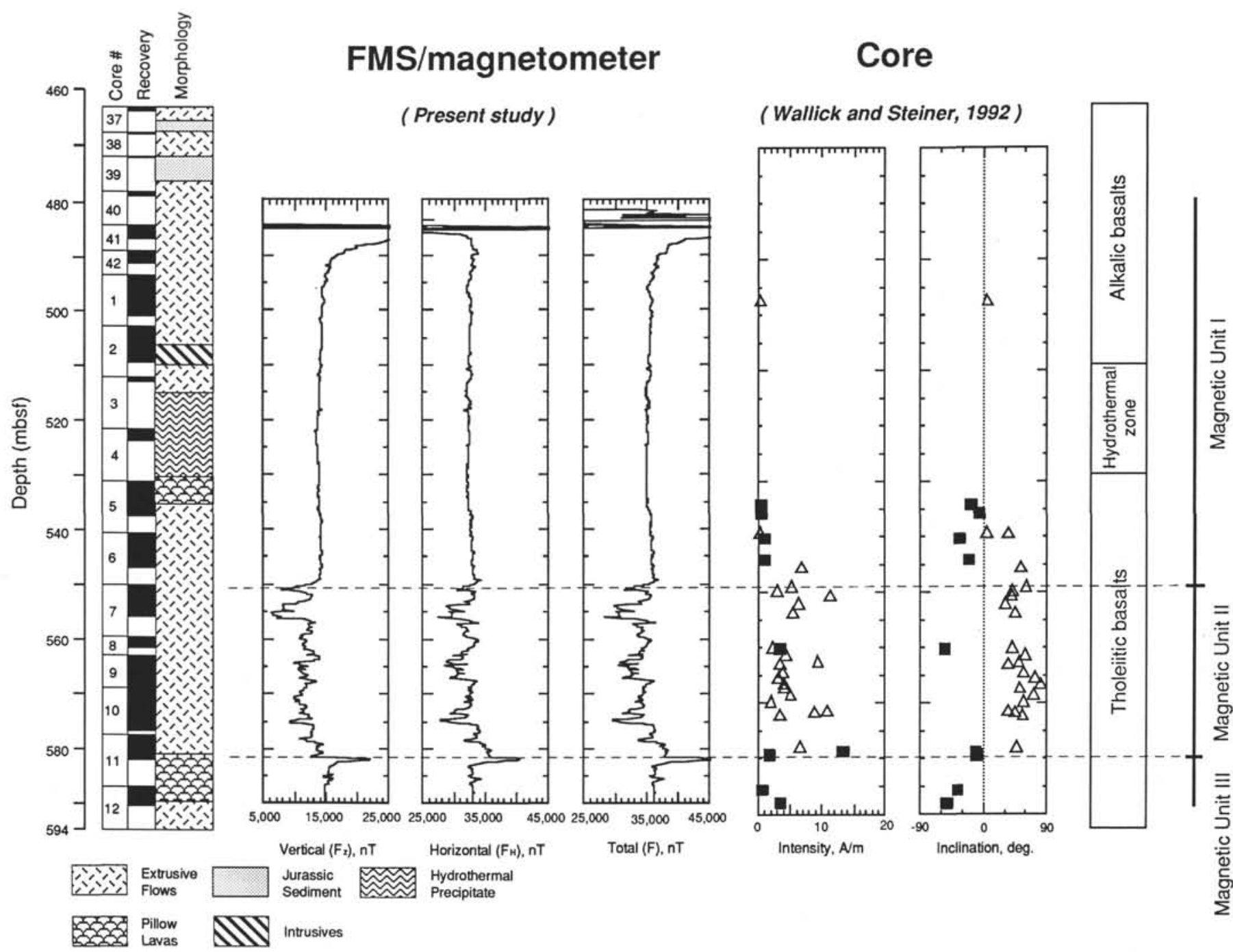

Figure 1. Downhole magnetic field data recorded in Jurassic basement, Hole 801C, obtained with the Schlumberger General Purpose Inclinometer Tool (GPIT) tool vs. the results of core sample measurements of Wallick and Steiner (1992). Solid squares depict data with negative inclinations, whereas open triangles show data with positive inclinations. Note that the depths of these samples are all $8 \mathrm{~m}$ shallower than those shown in Wallick and Steiner (1992) because of an error in that report. Also shown are magnetic Units I, II, and III, as determined by the intensity of spatial differential of the downhole magnetic field (ISDDM) and the signs of the vertical $\left(F_{Z}\right)$ and horizontal $\left(F_{H}\right)$ magnetic anomaly field components.

and downhole logging is necessary to understand most completely the magnetic nature of the oceanic crust and paleomagnetic stratigraphy.

Many attempts have been made to develop a three-component down-hole magnetometer and a method necessary to analyze the threecomponent data (Bosum and Scott, 1988; Gallet and Courtillot, 1989; Kinoshita et al., 1989; Bosum and Kopietz, 1990; Hamano and Kinoshita, 1990; Pariso and Johnson, 1993; Nogi et al., 1995b, 1995c). It has been demonstrated that three-component downhole magnetometer logging results can reveal the magnetic structure of the oceanic crust and thus lend insight into the origin of the magnetic anomaly lineations (Kinoshita et al., 1989; Hamano and Kinoshita, 1990; Pariso and Johnson, 1993), the magnetic structure of seamounts (Nogi et al., 1995b; Ito and Nogi, this volume), and the magnetization of sediments (Nogi et al., 1995c). Here we report the results of a three-component downhole magnetic field study in a borehole within the oceanic crust of the Jurassic Quiet Zone.

\section{SCHLUMBERGER GPIT}

A three-axis, flux-gate magnetometer, or general purpose inclinometer tool (GPIT), is routinely attached to a Schlumberger For- mation MicroScanner (FMS) tool to determine the horizontal tool orientation of the FMS relative to magnetic north within a borehole through weakly magnetized sediments or rocks. The measurements of the GPIT are low-pass filtered (third-order filter with a cut-off frequency of $15 \mathrm{~Hz}$ ), sampled at $60 \mathrm{~Hz}$. The quantification step is approximately $50 \mathrm{nT}$. The dynamic range is $\pm 100,000 \mathrm{nT}$, with maximum offset of $300 \mathrm{nT}$. The data are recorded every $15 \mathrm{~cm}$, whereas the FMS image data has a $2.5-\mathrm{mm}$ sampling rate (A. Dumont, pers. comm., 1992).

Because the GPIT originally was designed for general horizontal tool orientation, there are several problems with using GPIT data for detailed magnetic analysis. The most important of these is that $50 \mathrm{nT}$ of data resolution is insufficient for the analysis of small variations, or for the analyses of rocks that have weak magnetization, such as limestone. The magnetic anomaly caused by limestone is at most 10 nT. We can use the GPIT data to study the remanent magnetization of the basement at Hole $801 \mathrm{C}$ because the magnetic anomalies in this basalt section are large (up to $5000 \mathrm{nT}$ ) as compared with the data resolution. Also, Nogi et al. (1995c) compared the GPIT data with the Japanese downhole three-component magnetometer data obtained in the same borehole during Leg 143 . They noticed that a difference, or 
offset, of about $1000 \mathrm{nT}$ is present between the two tools in both horizontal and vertical components. However, they found that the relative changes of magnetic field variations in both the horizontal and vertical components of the GPIT with a wavelength between 5 and $50 \mathrm{~m}$ are reliable estimates of the gross features of magnetization in the borehole.

\section{DATA AND DATA PROCESSING}

Three passes of the Schlumberger FMS/GPIT logging string were made after a single pass of the geophysical tool string (dual induction tool, high-temperature lithodensity tool, borehole compensated sonic tool, compensated neutron tool, and natural gamma-ray spectrometry tool). The geophysical tool string and the first pass with the FMS/ GPIT (Fig. 1) extended to $587 \mathrm{mbsf}$, which is only $7 \mathrm{~m}$ above the total depth of Hole 801C (Shipboard Scientific Party, 1993). Subsequent FMS/GPIT runs could not pass the bridge formed at about $40 \mathrm{~m}$ above the bottom of the hole during the first FMS/GPIT pass.

The intensity of the spatial differential of the downhole magnetic field (ISDDM) (Fig. 2) and the polarity of magnetization were obtained following Nogi et al. (1995b). The polarity of magnetization and the hemisphere of acquisition were also determined by the signs of the horizontal and vertical components of the magnetic field with respect to the present magnetic field. However, an unknown amount of drift was observed in the magnetic field measured by the GPIT (Ito and Nogi, this volume). We estimated the uncertainty limits of this drift by setting them equal to the magnetic variation measured above 550 mbsf (Table 1). This is equivalent to assuming that all of the magnetic variation above $550 \mathrm{mbsf}$ is caused by instrument drift, which is unlikely. Thus, our uncertainty limits probably overestimate the amount of error caused by drift. The signs of the horizontal and vertical components of the magnetic field were defined using values above and below these uncertainty limits (Table 1). Magnetic field variations within the uncertainty limits were not used, and those sections of the hole are labeled "U" in the sign column of Figure 2.

Assuming that a cross section of the hole is a perfect circle, and that a cylindrical region around the hole is homogeneously magnetized, the vertical $\left(F_{Z}\right)$ and horizontal $\left(F_{H}\right)$ fields at $z=z_{0}$ within the hole and as a result of the magnetized body being bounded by $z=z_{1}$ and $z_{2}$, are expressed as follows:

$$
F_{H}=\pi m \cos I \frac{z_{0}-z}{\sqrt{\left(z_{0}-z\right)^{2}+R^{2}}}\left|\begin{array}{l}
z_{2} \\
z_{1}
\end{array}\right| \begin{aligned}
& R_{2} \\
& R_{1}
\end{aligned}
$$

and

$$
F_{Z}=-2 \pi m \sin I \frac{z_{0}-z}{\sqrt{\left(z_{0}-z\right)^{2}+R^{2}}}\left|\begin{array}{l}
z_{2} \\
z_{1}
\end{array}\right| \begin{aligned}
& R_{2} \\
& R_{1}
\end{aligned},
$$

where $z$ is depth (downward direction is taken as positive), $m$ is the intensity of magnetization, $I$ is the inclination of the magnetization, and $R_{1}$ and $R_{2}$ denote the radii of the hole and of the cylindrical magnetized body, respectively (Hamano and Kinoshita, 1990; Nogi et al., 1995c). The notational convention of

$$
f(x, y) \mid \begin{array}{l|l}
x_{2} & y_{2} \\
x_{1} & y_{1}
\end{array}=f\left(x_{2}, y_{2}\right)-f\left(x_{2}, y_{1}\right)-f\left(x_{1}, y_{2}\right)+f\left(x_{1}, y_{1}\right)
$$

is used.

If the present, regional magnetic field at the site, such as the IGRF90 field (IAGA Division V Working Group 8, 1991), is known, the vertical and horizontal fields caused by the surrounding magnetized body in the hole can be calculated. The inclination caused by a single, homogeneous, cylindrically magnetized body (called the apparent inclination) is directly obtained as follows:

$$
\mathrm{I}=\tan ^{-1}\left(-\frac{F_{Z}}{2 F_{H}}\right)
$$

When absolute values for the horizontal and vertical magnetic fields are not available and only the relative changes are reliable, the spatial differential of both components can be used to calculate the apparent inclination instead of the absolute values $F_{Z}$ and $F_{H}$. This relationship is easily derived from Equations 1 and 2, because the function of both of the components related to depth is the same.

We determined magnetic boundaries from variations of the horizontal and vertical magnetic fields in the hole. Peaks of the intensity of the spatial differential of the downhole magnetic field (ISDDM) were calculated as follows:

$$
\left|\frac{d F}{d z}\right|=\sqrt{\left(\frac{d F_{H}}{d z}\right)^{2}+\left(\frac{d F_{z}}{d z}\right)^{2}}=\text { ISDDM, }
$$

where $F_{H}$ and $F_{Z}$ are horizontal and vertical magnetic fields caused by the surrounding magnetized body. Smoothed differential values of the horizontal and vertical magnetic fields, according to Savitzky and Golay (1964), can be used to calculate apparent inclination so that the average features of apparent inclination can be estimated. Nine-point smoothing was performed. This smoothing interval corresponds to $1.35 \mathrm{~m}$. The threshold level of the ISDDM was taken as $5000 \mathrm{nT} / \mathrm{m}$ to determine magnetic subunit boundaries.

We can determine the polarity (normal or reverse) and hemisphere of origin (north or south) of remanent magnetization in a unique manner by inspecting the signs (positive or negative) of the horizontal and vertical magnetic anomaly components. These four possible magnetization configurations of polarity and hemisphere (Table 2) each have a unique combination of signed anomaly components when their remanent magnetic fields are added as vectors to the regional magnetic field components at the Hole $801 \mathrm{C}$ location.

This is useful and provides us new information from Hole 801C because the hemisphere of origin of this point on the Pacific Plate in the Middle Jurassic is unconstrained by plate kinematic reconstruction. That ambiguity, combined with the lack of horizontal orientation of the core samples, means it is impossible to distinguish, for example, between normally magnetized basalts formed in the Northern Hemisphere and reversely magnetized basalts formed in the Southern Hemisphere, simply with the remanent inclination of the basalt samples.

Apparent inclinations (Fig. 3) (Nogi et al., 1995b) also were obtained using the ratio of the differential value of vertical to horizontal components of the magnetic field. This was only calculated for the portion of the section where the vertical/horizontal component ratio is positive (Fig. 2; Table 2), because this positive ratio indicates a Southern Hemisphere origin and, therefore, the primary magnetization of the Jurassic oceanic crust. A negative ratio indicates a Northern Hemisphere origin, which is likely to be a secondary overprint for Hole $801 \mathrm{C}$

\section{RESULTS}

\section{Magnetic Units Derived from ISDDM}

Figure 1 shows the three-component magnetometer results. Above about 495 mbsf, a large amount of disturbance seen in the downhole magnetic field was caused by the iron casing pipe, which was set down to 481 mbsf during Leg 129 (Shipboard Scientific Party, 1990). Both the horizontal and vertical magnetic intensities between 495 and 550 mbsf stay almost constant, and no significant magnetic variations were observed. These data suggest that measurements within this zone represent only the ambient, present-day field and a small amount of instrument drift. There are two general changes in the magnetic intensities below this level, which define the boundaries between magnetic Units I, II, and III as described below. At about $550 \mathrm{mbsf}$, general 


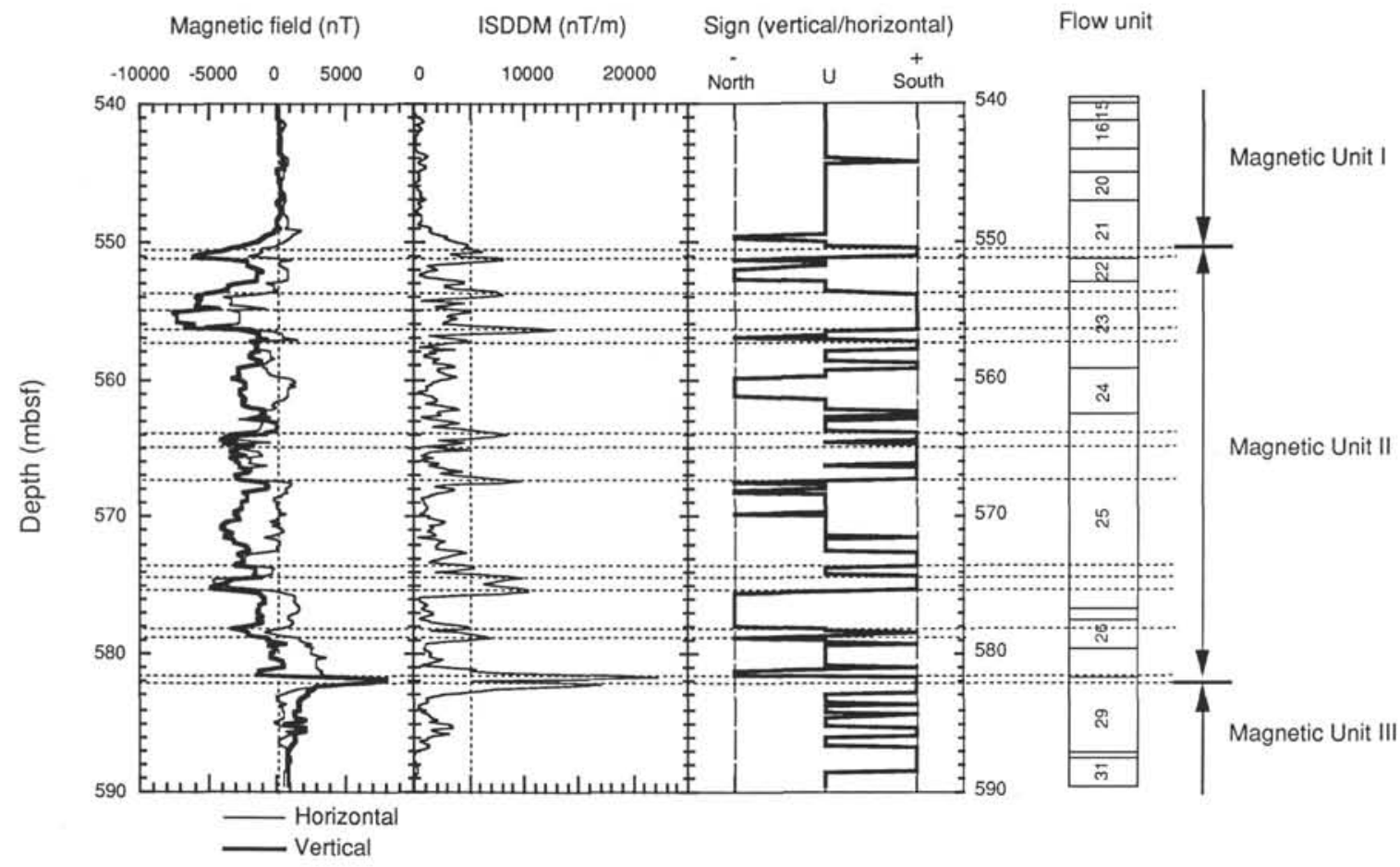

Figure 2. Magnetic properties and igneous flow units in Hole 801C. The horizontal dashed lines depict the magnetic subunits defined from the ISDDM (see Eq. 5 in the text) peaks that are greater than $5000 \mathrm{nT} / \mathrm{m}$. Signs (vertical/horizontal) determine the hemisphere in which the magnetization was acquired, with a positive sign indicating the Southern Hemisphere and a negative sign indicating the Northern Hemisphere. $U=$ unknown, because in those intervals at least one of the field components is within its uncertainty limits (see text and Table 1) where this sign ratio calculation was not made. Igneous flow units are from Floyd and Castillo (1992).

Table 1. Uncertainty limits of regional field components determined from magnetic variations above $\mathbf{5 5 0}$ mbsf.

\begin{tabular}{lllc}
\hline & Minimum & Maximum & Total uncertainty \\
\hline $\begin{array}{l}\text { Horizontal components } \\
\text { Vertical components }\end{array}$ & $32,668 \mathrm{nT}$ & $32,917 \mathrm{nT}$ & $\Delta \mathrm{nT}=249$ \\
& $13,156 \mathrm{nT}$ & $14,375 \mathrm{nT}$ & $\Delta \mathrm{nT}=1219$ \\
\hline
\end{tabular}

decreases are seen in both the vertical and horizontal components of the downhole magnetic field; at about $583 \mathrm{mbsf}$, general increases are seen in both the vertical and horizontal components of the downhole magnetic field.

The calculated ISDDM and the sign of the vertical/horizontal component ratio are shown in Figure 2. A vertical/horizontal component ratio with a positive sign indicates that magnetization of the surrounding materials was acquired in the Southern Hemisphere. Conversely, a negative sign shows that the magnetization originated in the Northern Hemisphere.

These general features are consistent with the results from the recovered core samples shown in Figure 2 (Shipboard Scientific Party, 1990; Wallick and Steiner, 1992). The NRM intensities measured for the recovered core samples of Sections 129-801C-5R-1 through $-6 \mathrm{R}-1$ in alkali basalts have low values (as low as the order of $10^{-4} \mathrm{~A} / \mathrm{m}$ ), whereas those in the tholeiite basalts are generally high (weighted $\log$ mean of $2.3 \mathrm{~A} / \mathrm{m}$ ).

We introduce three major magnetic units based on the general magnetic logging results. The first unit is above $550 \mathrm{mbsf}$ and consists of the alkalic basalts, the hydrothermal zone, and the upper part of the tholeiitic basalts. It is characterized by almost no magnetization. The second magnetic unit is between 550 and 583 mbsf in the tholeitic basalts. These rocks display magnetization that mainly was acquired in the Southern Hemisphere during a reversed polarity chron. In the third unit (below 583 mbsf in the tholeiite basalts), magnetization acquired in the Southern Hemisphere during a normal polarity chron
Table 2. Magnetic polarity and hemisphere of origin determined by signs of horizontal and vertical magnetic anomaly components.

\begin{tabular}{|c|c|c|c|c|}
\hline Hemisphere & Polarity & $\begin{array}{c}\text { Sign of } \\
\text { horizontal } \\
\text { field }\end{array}$ & $\begin{array}{l}\text { Sign of } \\
\text { vertical } \\
\text { field }\end{array}$ & $F_{Z} / F_{H}$ \\
\hline \multirow[t]{2}{*}{ Northern } & Normal & + & - & - \\
\hline & Reverse & - & + & - \\
\hline \multirow[t]{2}{*}{ Southern } & Normal & + & + & + \\
\hline & Reverse & - & - & + \\
\hline
\end{tabular}

was recognized. The intensity of magnetization below 583 mbsf seems to decrease rapidly with depth in the hole. A clear change from reversed to normal magnetic polarity was observed between the second and third units at about 583 mbsf, where the polarity of both components goes from negative to positive (Figs. 1 and 2). Because the majority of the strong magnetization was acquired in the Southern Hemisphere and Hole $801 \mathrm{C}$ is now located at $18^{\circ} 39^{\prime} \mathrm{N}$, we conclude that this is the primary magnetization component, and that the tholeiitic basalts in Hole $801 \mathrm{C}$ formed at a spreading ridge crest in the Southern Hemisphere.

Within magnetic Unit II, it appears that there are several subunits based on a detailed examination of the magnetic intensities (Fig. 1) and the ISDDM (Fig. 2). We determined subunits within magnetic Unit II from the ISDDM peaks that exceed $5000 \mathrm{nT} / \mathrm{m}$. Normal magnetization acquired in the Northern Hemisphere was observed within some of these subunits. These magnetizations are considered to be viscous or induced magnetization by the present magnetic field at the site.

In magnetic Unit III, the calculated apparent inclination, together with the sign and variation, shows that the magnetization of this unit was acquired in the Southern Hemisphere during a normal polarity chron. This is probably primary magnetization and is unlike the 
several thin magnetic subunits within the second unit whose magnetization was subsequently acquired in the Northern Hemisphere during a normal polarity chron.

\section{Amplitude}

Assuming a cylindrical magnetized body, a $1 \mathrm{~A} / \mathrm{m}$ magnetization produces an approximate $1000 \mathrm{nT}$ anomaly at the magnetic boundary. Amplitudes of the magnetic field variations in the horizontal and vertical components (Fig. 1) suggest that the intensity of primary magnetization acquired in the Southern Hemisphere is about $5 \mathrm{~A} / \mathrm{m}$. Indeed, amplitudes of the sharp decreases and increases in the magnetic variations are about $5000 \mathrm{nT}$. Therefore, magnetization of the surrounding body in Hole $801 \mathrm{C}$ is estimated at about $5 \mathrm{~A} / \mathrm{m}$. The intensity of NRM from Sections 129-801C-6R-4 through -12R-2 ranges from 0.26 to $13.27 \mathrm{~A} / \mathrm{m}$ (Wallick and Steiner, 1992), which is concordant with measurements estimated from the downhole magnetometer logs (Fig. 1).

\section{Apparent Inclination}

The apparent magnetic inclination of these portions of the section magnetized in the Southern Hemisphere is about $23^{\circ}$ (Fig. 3). This value is somewhat shallower than those obtained by the paleomagnetic core samples (Wallick and Steiner, 1992). A significant contribution of the viscous or induced magnetization may cause the shallower inclinations seen in the downhole magnetometer logs. If the apparent inclination results only from remanent magnetization, this implies a paleolatitude of $12^{\circ} \mathrm{S}$

\section{DISCUSSION}

\section{Comparison with Geophysical Logging and Flow Units}

In Figure 4, geophysical logging results are compared with the magnetic boundaries determined by the ISDDM. The boundary between magnetic Units I and II at 550.5 mbsf is well correlated with some of the other geophysical logging results. The peaks of the ISDDM correlate very well with the flow unit boundaries (Fig. 2) and other geophysical logging results. For example, the boundary between magnetic Units I and II corresponds to the boundary between flow units 21 and 22 (Fig. 2) and distinct changes in resistivity, porosity, and $P$-wave velocity (Fig. 4). The ISDDM peak at $564 \mathrm{mbsf}$ corresponds to the boundary between flow unit 24 and 25 and distinct changes in resistivity and porosity.

Moos et al. (this volume) calculated both $P$ - and $S$-wave velocities from full-wave sonic data. In the alkali basalts, both the $P$ - and $S$-wave velocities are almost constant except in the depth interval $502-510$ mbsf, whereas in the tholeiites the velocities are quite variable with several thin layers that have low velocities (Fig. 4). Moos et al. (this volume) and Jarrard et al. (this volume) proposed the cause of these narrow, low-velocity layers to be due either to the accessibility of these materials to circulating fluids, which may have caused them to be more altered than the flow interiors, or to the fact that they were originally more porous, and infilling did not entirely eliminate the differences in their physical properties compared to the adjacent materials. Shallow resistivity data (Fig. 4) show that low-resistivity zones correlate with low-velocity zones, and ISDDM peaks and suggest that alteration caused by fluid flow is responsible for physical and magnetic properties. The degree of alteration might be different for different flow units.

\section{Alteration of Hole 801C}

According to Alt et al. (1992), the lower basalt section is tholeiitic, normal mid-ocean-ridge basalt (N-MORB) formed at an active Jurassic spreading center, whereas the upper basalt section consists of alkalic ocean-island-type basalts formed during subsequent, off-axis

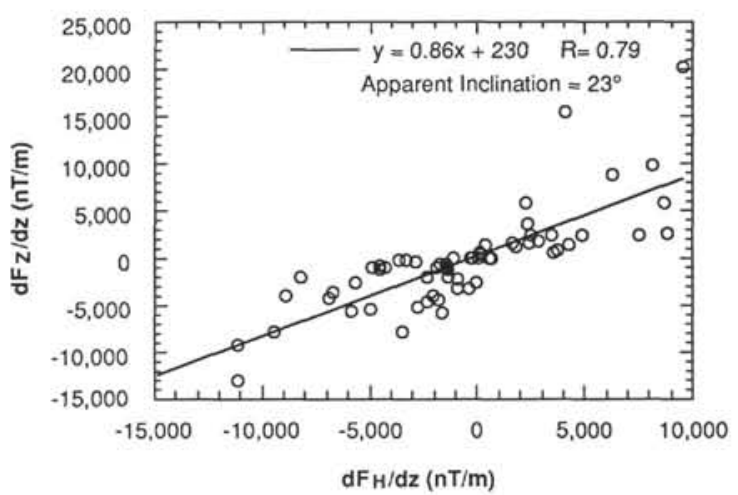

Figure 3. Apparent inclination, calculated (see Eq. 4 in the text) by correlating between the spatial differentials of the horizontal and vertical magnetic field components in Hole $801 \mathrm{C}$.

volcanism. Alt et al. (1992) found four types of alteration in the tholeiitic basalts. Among them, celadonite-type alteration indicates higher seawater/rock ratios and oxidizing conditions. They also point out that the veins in cores beneath the hydrothermal deposit were probably pathways for iron- and silica-rich fluids similar to those that formed the hydrothermal deposit. Thus, there might be some correlation between magnetic variations and secondary magnetization caused by alteration in magnetic Unit $I$.

\section{Comparison with Magnetic Properties of Core Samples}

Wallick and Steiner (1992) suggest that the Earth's magnetic field experienced frequent changes in polarity during the Middle Jurassic, and this period of frequent reversals offered the best explanation for the low-amplitude, incoherent magnetic anomalies within the Jurassic Quiet Zone. However, we interpret only one Jurassic polarity reversal in the section at $583 \mathrm{mbsf}$, the boundary between magnetic Units II and III. Other short normal polarity intervals within Unit II were acquired subsequently in the Northern Hemisphere and are probably a result of hydrothermal alteration.

\section{Significance for the Jurassic Quiet Zone}

The magnetic smooth zone in the western central Pacific is commonly referred to as the Jurassic Quiet Zone and is bounded by the M25 magnetic lineation (Larson, 1976). A variety of mechanisms have been proposed to explain the Jurassic Quiet Zone, including diagenetic processes by Pitman et al. (1968), the effect of thickening of low velocity-layer $2 \mathrm{~A}$ crustal rocks associated with the Jurassic Quiet Zone by Houtz and Ewing (1976), an increase in viscous magnetization with age (e.g., Lowrie, 1973), and a progressive demagnetization of the source layer with time by Blakely (1983). A popular theory was that the Jurassic Quiet Zone was caused by an interval of constant magnetic polarity during the Early and Middle Jurassic, which produced a magnetic quiet zone similar to that of the mid-Cretaceous Long Normal Superchron (Heirtzler et al., 1968; Emery et al., 1970; Poehls et al., 1973; Hayes and Rabinowitz, 1975). A reduced strength of the Earth's dipole field at the time of emplacement of the Quiet Zone basalts (Vogt et al., 1971; Larson and Hilde, 1975; Cande et al., 1978) and gradual reduction in field strength (Larson and Pitman, 1972) were also proposed to explain the nature of the Quiet Zone.

Steiner and Ogg (1987) and Handschumacher et al. (1988) have argued that the Jurassic Quiet Zone basalts were emplaced during a period of extremely frequent reversals. Wallick and Steiner (1992), Steiner and Wallick (1992) suggested that frequent changes in polarity occurred during the Jurassic, based on paleomagnetic measurements of the discrete core samples obtained during Leg 129.

The present results suggest that evidence is present of only one Jurassic polarity reversal in the Hole $801 \mathrm{C}$ section, although the time 


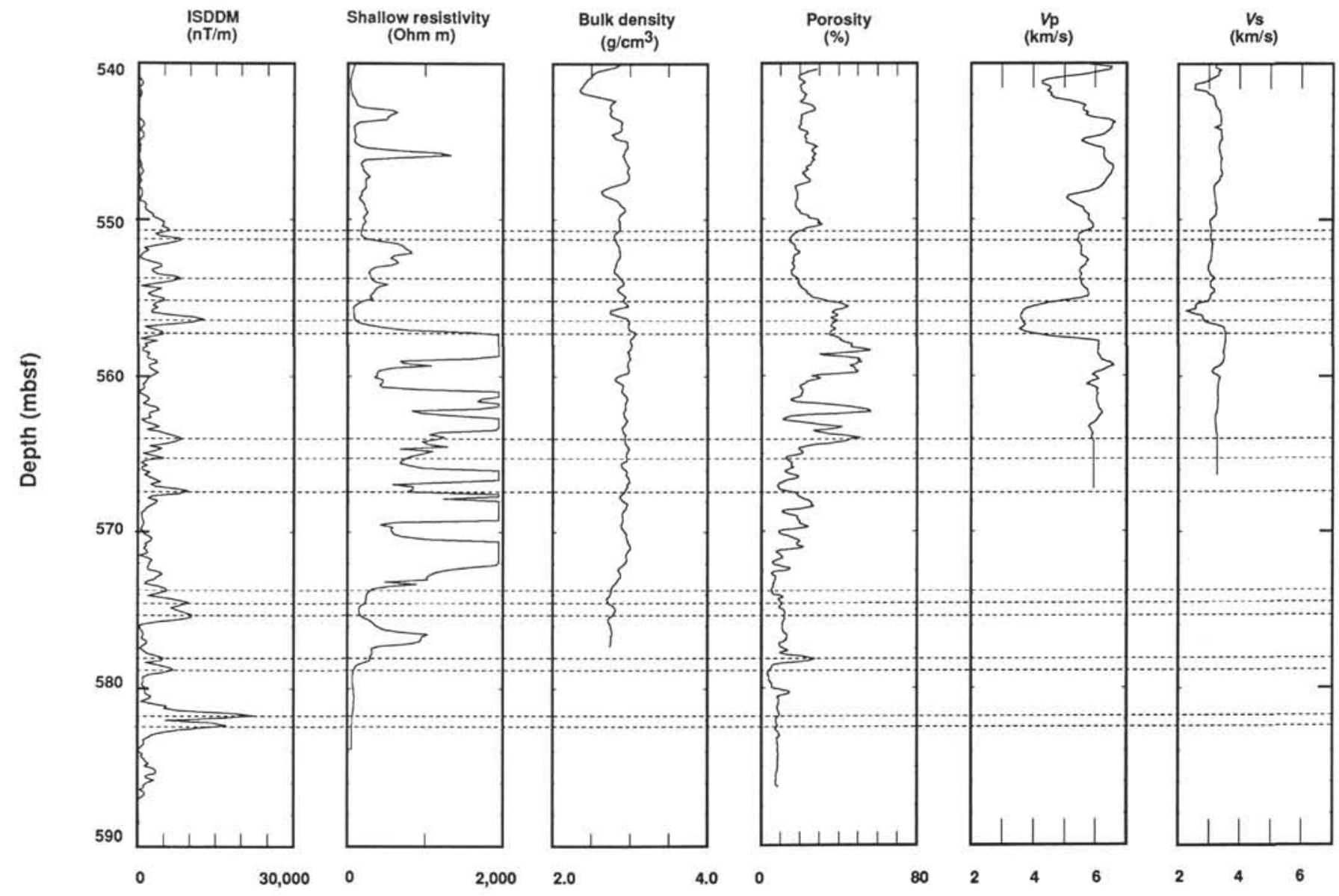

Figure 4. Geophysical logging measurements in Hole 801C and ISDDM. The $V_{p}$ and $V_{s}$ velocities are calculated from the full-wave sonic data (Moos et al., this volume).

span over which these tholeiitic basalts were emplaced is unknown. Primary magnetization in the entire second magnetic unit (II) was acquired in the Southern Hemisphere during a reversed magnetic polarity chron; and, after the acquisition of primary magnetization, it partially suffered remagnetization induced by hydrothermal alteration. However, the intensity of the secondary magnetization is weak, and the entire, 70 -m-thick section of Unit I is essentially nonmagnetic because of this alteration. This suggests that one possible cause of the Jurassic Quiet Zone at this location is the reduction of primary magnetization induced by hydrothermal alteration. Because the Jurassic Quiet Zone is time coincident throughout the world's ocean basins, it is unlikely that hydrothermal alteration is the general explanation for this feature. However, this result at Hole $801 \mathrm{C}$ reemphasizes the importance of hydrothermal alteration as an agent of ocean crustal aging (Larson et al., 1993).

\section{CONCLUSIONS}

The majority of the strongly magnetized basalts in magnetic Units II and III acquired their primary magnetization at a spreading ridge crest in the Southern Hemisphere during the Middle Jurassic. The cause of the very weak magnetization of magnetic Unit I and the rapid decrease in intensity within Unit III is considered to be the result of subsequent, strong hydrothermal alteration. Several thin magnetic subunits were observed within Unit II. The magnetization of those subunits was acquired in the Northern Hemisphere during a normal polarity chron. These Northern Hemisphere, normally magnetized sections were also possibly caused by secondary magnetization induced by hydrothermal alteration.

Wallick and Steiner (1992) suggested frequent changes in polarity during the Jurassic based on paleomagnetic measurements of the discrete core samples. Our results from the downhole magnetometer logging suggest only one reversal in polarity, and the primary magnetization in the entire Unit II was acquired in the Southern Hemisphere during a reversed magnetic polarity chron. After the acquisition of primary magnetization, it partially suffered remagnetization because of hydrothermal alteration. These various lines of evidence suggest that the cause of the Jurassic Quiet Zone at this location is the reduction of primary magnetization caused by hydrothermal alteration, although this probably is not the general explanation of this worldwide feature.

\section{ACKNOWLEDGMENTS}

We thank all of the shipboard party for their kind help and encouragement, both during and after ODP Leg 144. H.I. is grateful to the members of Geothermal Research Department, Geological Survey of Japan, for their encouragement and understanding. We thank the Ocean Research Institute, the University of Tokyo, the University of Rhode Island, and ODP for providing us the opportunity to participate on Leg 144. We also are grateful to R. Jarrad and D. Moos for discussions on logging data. Critical reviews by B. Wallick and J. P. Pozzi greatly improved the manuscript. 


\section{REFERENCES}

Alt, J.C., France-Lanord, C., Floyd, P.A., Castillo, P., and Galy, A., 1992. Low-temperature hydrothermal alteration of Jurassic ocean crust, Site 801. In Larson, R.L., Lancelot, Y., et al., Proc. ODP, Sci. Results, 129: College Station, TX (Ocean Drilling Program), 415-427.

Blakely, R.J., 1983. Statistical averaging of marine magnetic anomalies and the aging of oceanic crust. J. Geophys. Res., 88:2289-2296.

Bosum, W., and Kopietz, J., 1990. BGR magnetometer logging in Hole 395A, Leg 109. In Detrick, R., Honnorez, J., Bryan, W.B., Juteau, T., et al., Proc. ODP, Sci. Results, 106/109: College Station, TX (Ocean Drilling Program), 309-313.

Bosum, W., and Scott, J.H., 1988. Interpretation of magnetic logs in basalt, Hole 418A. In Salisbury, M.H., Scott, J.H., et al., Proc. ODP, Sci. Results, 102: College Station, TX (Ocean Drilling Program), 77-95,

Cande, S.C., Larson, R.L., and LaBrecque, J.L., 1978. Magnetic lineations in the Pacific Jurassic Quiet Zone. Earth Planet. Sci. Lett., 41:434-440.

Emery, K.O., Uchupi, E., Phillips, J.D., Bowin, C.O., Bunce, E.T., and Knott, S.T., 1970. Continental rise off Eastern North America. AAPG Bull., $54: 44-108$

Floyd, P.A., and Castillo, P.R., 1992. Geochemistry and petrogenesis of Jurassic ocean crust basalts, Site 801. In Larson, R.L., Lancelot, Y., et al., Proc. ODP, Sci. Results, 129: College Station, TX (Ocean Drilling Program), 361-388.

Gallet, Y., and Courtillot, V., 1989. Modeling magnetostratigraphy in a borehole. Geophysics, 54:973-983.

Hamano, Y., and Kinoshita, H., 1990. Magnetization of the oceanic crust inferred from magnetic logging in Hole 395A. In Detrick, R., Honnorez, J., Bryan, W.B., Juteau, T., et al., Proc. ODP, Sci. Results, 106/109: College Station, TX (Ocean Drilling Program), 223-229.

Handschumacher, D.W., Sager, W.W., Hilde, T.W.C., and Bracey, D.R., 1988. Pre-Cretaceous tectonic evolution of the Pacific Plate and extension of the geomagnetic polarity reversal time scale with implications for the origin of the Jurassic "Quiet Zone." Tectonophysics, 155:365-380.

Hayes, D.E., and Rabinowitz, P.D., 1975. Mesozoic magnetic lineations and the magnetic quiet zone off northwest Africa. Earth Planet. Sci. Lett., 28:105-115.

Heirtzler, J.R., Dickson, G.O., Herron, E.M., Pitman, W.C., and Le Pichon, X., 1968. Marine magnetic anomalies, geomagnetic field reversals, and motions of the ocean floor and continents. J. Geophys. Res., 73:21192136 .

Houtz, R., and Ewing, J., 1976. Upper crustal structure as a function of plate age. J. Geophys. Res., 81:2490-2498.

IAGA Division V Working Group 8, 1991. International Geomagnetic Reference Field 1991 revision. J. Geomagn. Geoelectr., 43:1007-1012.

Kikawa, E., and Pariso, J.E., 1991. Magnetic properties of gabbros from Hole 735B, Southwest Indian Ridge. In Von Herzen, R.P., Robinson, P.T., et al., Proc. ODP, Sci. Results, 118: College Station, TX (Ocean Drilling Program), 285-307.

Kinoshita, H., Furuta, T., and Pariso, J., 1989. Downhole magnetic field measurements and paleomagnetism, Hole 504B, Costa Rica Ridge. In Becker, K., Sakai, H., et al., Proc. ODP, Sci. Results, 111: College Station, TX (Ocean Drilling Program), 147-156.

Lancelot, Y., Larson, R.L., et al., 1990. Proc. ODP, Init. Repts., 129: College Station, TX (Ocean Drilling Program).

Larson, R.L., 1976. Late Jurassic and Early Cretaceous evolution of the western Central Pacific Ocean. J. Geomagn. Geoelectr., 28:219-236.

Larson, R.L., Fisher, A.T., Jarrard, R.D., Becker, K., and Ocean Drilling Program Leg 144 Shipboard Scientific Party, 1993. Highly permeable and layered Jurassic oceanic crust in the western Pacific. Earth Planet. Sci. Lett., 119:71-83.

Larson, R.L., and Hilde, T.W.C., 1975. A revised time scale of magnetic reversals for the Early Cretaceous and Late Jurassic. J. Geophys. Res., 80:2586-2594.

Larson, R.L., and Pitman, W.C., III, 1972. World-wide correlation of Mesozoic magnetic anomalies and its implications. Geol. Soc. Am. Bull., 83:36453662 .
Lowrie, W., 1973. Viscous remanent magnetization in ocean basalt. Nature, 243:27-30.

Nogi, Y., Taruduno, J.A., and Sager, W.W., 1995a. Geomagnetic-field variations recorded within drill pipes at Site 865: implications for paleomagnetic studies. In Winterer, E.L., Sager, W.W., Firth, J.V., and Sinton, J.M. (Eds.), Proc. ODP, Sci. Results, 143: College Station, TX (Ocean Drilling Program), 389-393.

1995b. Inferences about the nature and origin of basalt sequences from the Cretaceous Mid-Pacific Mountains (Sites 865 and 866), as deduced from downhole magnetometer logs. In Winterer, E.L., Sager, W.W., Firth, J.V., and Sinton, J.M. (Eds.), Proc. ODP, Sci. Results, 143: College Station, TX (Ocean Drilling Program), 381-388.

1995c. Magnetization of seamount-derived sediments from Site 869 inferred from downhole magnetometer logs. In Winterer, E.L., Sager, W.W., Firth, J.V., and Sinton, J.M. (Eds.), Proc. ODP, Sci. Results, 143: College Station, TX (Ocean Drilling Program), 373-379.

Pariso, J.E., and Johnson, H.P., 1993. Do layer 3 rocks make a significant contribution to marine magnetic anomalies? In situ magnetization of gabbros at Ocean Drilling Program Hole 735B. J. Geophys. Res., 98:16033-16052.

Pariso, J.E., Scott, J.H., Kikawa, E., and Johnson, H.P., 1991. A magnetic logging study of Hole 735B gabbros at the Southwest Indian Ridge. In Von Herzen, R.P., Robinson, P.T., et al., Proc. ODP, Sci. Results, 118: College Station, TX (Ocean Drilling Program), 309-321.

Pitman, W.C., III, Herron, E.M., and Heirtzler, J.R., 1968. Magnetic anomalies in the Pacific and sea floor spreading. J. Geophys. Res., 73:2069-2085.

Poehls, K.A., Luyendyk, B.P., and Heirtzler, J.R., 1973. Magnetic smooth zones in the world's oceans. J. Geophys. Res., 78:6985-6997.

Pringle, M.S., 1992. Radiometric ages of basaltic basement recovered at Sites 800, 801, and 802, Leg 129, western Pacific Ocean. In Larson, R.L., Lancelot, Y., et al., Proc. ODP, Sci. Results, 129: College Station, TX (Ocean Drilling Program), 389-404.

Savitzky, A., and Golay, M.J.E., 1964. Smoothing and differential of data by simplified least square procedure. Anal. Chem., 36:1627-1639.

Shipboard Scientific Party, 1990. Site 801. In Lancelot, Y., Larson, R.L., et al., Proc. ODP, Init. Repts., 129: College Station, TX (Ocean Drilling Program), 91-170.

1993. Site 801. In Premoli Silva, I., Haggerty, J., Rack, F., et al., Proc. ODP, Init. Repts., 144: College Station, TX (Ocean Drilling Program), 313-329.

Steiner, M.B., and Ogg, J.G., 1987. Oxfordian magnetic polarity pattern, reply to comment by R.E. Sheridan and K.A. Suydam. Earth Planet. Sci. Lett., $85: 323-325$.

Steiner, M.B., and Wallick, B.P., 1992. Jurassic to Paleocene paleolatitudes of the Pacific Plate derived from the paleomagnetism of the sedimentary sequences at Sites 800, 801, and 802. In Larson, R.L., Lancelot, Y., et al., Proc. ODP, Sci. Results, 129: College Station, TX (Ocean Drilling Program), $431-446$.

Vogt, P.R., Anderson, C.N., and Bracey, D.R., 1971. Mesozoic magnetic anomalies, sea-floor spreading, and geomagnetic reversals in the southwestern Atlantic. J. Geophys. Res., 76:4796-4823.

Wallick, B.P., and Steiner, M.B., 1992. Paleomagnetic and rock magnetic properties of Jurassic Quiet Zone basalts, Hole 801C. In Larson, R.L., Lancelot, Y., et al., Proc. ODP, Sci. Results, 129: College Station, TX (Ocean Drilling Program), 455-470.

\footnotetext{
- Abbreviations for names of organizations and publications in ODP reference lists follow the style given in Chemical Abstracts Service Source Index (published by American Chemical Society).
}

Date of initial receipt: 2 February 1994

Date of acceptance: 22 September 1994

Ms 144SR-024 